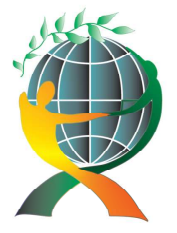

\author{
(online) $=$ ISSN $2285-3642$ \\ ISSN-L = $2285-3642$ \\ Journal of Economic Development, Environment and People \\ Volume 5, Issue 1, 2016
}

URL: http://jedep.spiruharet.ro

e-mail: office jedep@spiruharet.ro

\title{
Eco Industrial Development: As a Way of Enhancing Sustainable Development
}

\author{
Begum Sertyesilisik ${ }^{1}$ and Egemen Sertyesilisik ${ }^{2}$ \\ ${ }^{1}$ Istanbul Technical University \\ ${ }^{2}$ Political Scientist
}

\begin{abstract}
The world's habitat is being deteriorated especially due to the unsustainable production. The need for sustainable development and reducing humanities' environmental footprint have been addressed in various international frameworks, meetings and reports (e.g. Kyoto protocol, the Resource Efficiency and Cleaner Production Program, the Ten Year Framework of Programs on Sustainable Consumption and Production, the UN Resource Panel, and the Green Economy Initiative, Rio+20, green building certificates, "UNEP Green Economy" in 2011, "Green New Deal" in 2012, the Intergovernmental Panel on Climate Change's report etc.). EIDs (the eco industrial development) can act as catalysts in sustainable development and in reducing environmental footprint of the production processes. Based on an in-depth literature review, this paper aims to analyze how EID can be supported so that environmental footprint of the production processes can be reduced contributing to sustainable development. With this aim, the objectives include: analysis of the need for the EID; need for the sustainable development enhanced by sustainable production and sustainable products; key success factors for, barriers against and drivers for the EID. The policymakers, companies, and researchers are expected to get benefit from this paper.
\end{abstract}

Keywords: eco industrial development, eco industrial parks, sustainable production.

JEL Codes: O1, Q5, ZOO

\section{Introduction}

The world's habitat is being deteriorated (i.e. water depletion, loss of biodiversity) (Tukker, 2013: 274). The growing industrialization and increase in the scale of economic activity have transformed the world's resources into wealth causing adverse effects on ecosystems and resources (Linnenluecke and Griffiths, 2013: 382). Nature is under the combined pressure of human population growth and the growth in the wealth per capita (Tukker and Butter, 2007: 102). The 'economy is crashing against the Earth' (Tukker, 2013: 274). The world economy is expected to grow by 3\% per year until 2030 and more than 9 billion

\footnotetext{
${ }^{1}$ E-mail address: begum_sertyesilisik@hotmail.com

${ }^{2}$ E-mail address: egemens@alumni.bilkent.edu.tr
} 


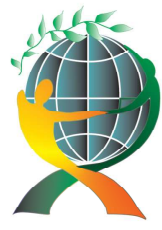

\author{
(online) $=$ ISSN $2285-3642$ \\ ISSN-L = 2285 - 3642 \\ Journal of Economic Development, Environment and People \\ Volume 5, Issue 1, 2016 \\ URL: http://jedep.spiruharet.ro \\ e-mail: office jedep@spiruharet.ro
}

humans are expected to live on earth by 2050 (Rohn et al., 2014: 32). The economic growth puts pressure on the environment (Tukker and Butter (2007: 102).

The economic growth's adverse effect on the environment is expected to be increased due to the need for a US\$200 trillion global economy by 2050 to eradicate the poverty, while not affecting the income of the rich, as well as fulfilling the aspirations and expectations of the middle class (Tukker, 2013: 272). The economy needs to be sustainable. An economy is sustainable only if it simultaneously caters human needs - in particular the essential needs of the world's poor - and accepts the limitations imposed by the need to sustain the environment's ability to meet present and future needs (Lorek and Spangenberg, 2014: 33).

Despite of rising prices for natural resources during the past 30 years, there is increase in the global consumption of natural resources (Rohn et al., 2014: 32). The Earth, however, has its limitations (Ayres and Kneese, 1969; Daly, 1991; Meadows et al., 1972; Tukker, 2013: 272). As stated by The Club of Rome's (1972) Limits to Growth, economic growth cannot continue indefinitely due to the limits of the capacity of the global environment (Jung et al., 2013). Essential needs are not substitutable and as limits are clearly referring to the environment, and not to natural capital or a substitute thereof? (Lorek and Spangenberg, 2014: 33). As the environmental degradation continues to occur in an accelerated way, time is of the essence for taking effective precautions. The report from the Intergovernmental Panel on Climate Change (IPCC) called for immediate action (EC website, 2014). The fact that the world's habitat is being deteriorated (i.e. climate is changing, the earth's temperature is rising, and the earth resources are being exploited) despite of the precautions (e.g. Kyoto protocol, the Resource Efficiency and Cleaner Production (RECP) Program, the Ten Year Framework of Programs on Sustainable Consumption and Production (10-YFP on SCP), the UN Resource Panel, and the Green Economy Initiative (GEI), Rio+20, green building certificates, "UNEP Green Economy" in 2011, "Green New Deal" in 2012 etc.) taken reveals the need for acting strategically (e.g. encouraging ecoindustrial development, enabling sustainability transition, degrowth, dematerialization, and encouraging the change agents for sustainability) for the survival of humanity considering technical, and socio-economical aspects and reducing the footprint of the humanity (including, production processes).

CE (Circular economy) and IE (Industrial ecology) enhanced by the EID (eco industrial development) need to be encouraged for reducing humanities' environmental footprint. CE is based on (Stahel and Reday, 1982): perception of waste as food or input; perception of diversity as strength; relying on renewable energy sources; and systems thinking. The CE encompasses principles mainly from: closed loop system; biomimicry; IE; and cradle-to-cradle. IE can be defined as a community of manufacturing and service business collaborating for economic and environmental benefit by managing energy, water, materials and other resources (Love et al., 1996).? (Zhu and Cote, 2004: 1025). IE is based on a complex and selforganized closed-loop system similar to that in nature (Panyathanakun et al., 2013: 71) and transforms the industrial system and minimizes inefficiencies by learning and mimicking from the natural environment and how natural environment works (Chertow, 2000; Graedel and Allenby, 2003; Korhonen, 2007; Lambert and Boons, 2002; Pakarinen et al. 2010; Romerao and Ruiz, 2014). IE can contribute to the sustainable growth (Panyathanakun et al., 2013: 71). 


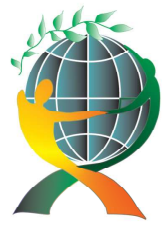

\author{
(online) $=$ ISSN $2285-3642$ \\ ISSN-L = $2285-3642$ \\ Journal of Economic Development, Environment and People \\ Volume 5, Issue 1, 2016 \\ URL: $\underline{\text { http://jedep.spiruharet.ro }}$ \\ e-mail: office jedep@spiruharet.ro
}

IE is supported by the EID (eco industrial development) which is a framework for the development of the industry reducing its adverse effects to the environment (Cohen-Rosenthal, 2003). EID is based on the biological symbiosis and on the closed loop production cycle principles (Lown, 2003). Mutually beneficial connections among industry, natural systems, energy, material and local communities are considered as central factors in designing industrial production processes (Cohen-Rosenthal, 1999). EID aims to improve business and environmental performances mainly through: resource efficiency (Babu and Meyer, 2012); cleaner product; IE; industrial symbiosis; environmental management systems; and design for the environment.

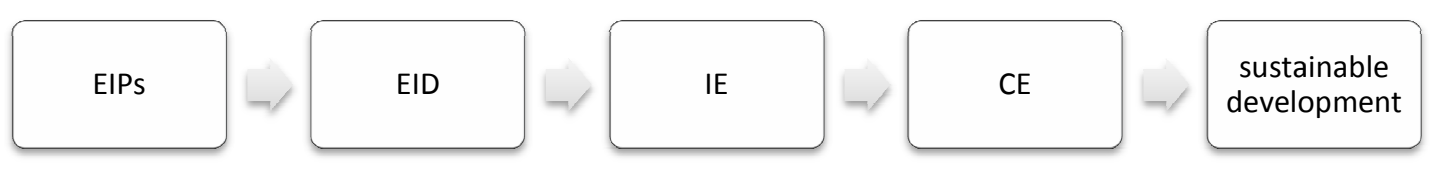

Fig. 1: The relationship among EIPs, EID, IE, and CE

An important application of the IE concept is EIP (the Eco-Industrial Park) (Panyathanakun et al., 2013: 71). EIP can be defined as "a community of manufacturing and service businesses located together on a common property. Member businesses seek enhanced environmental, economic, and social performance through collaboration in managing environmental and resource issues" (Veiga and Magrini, 2009: 653). EIPs lead to the EID which supports IE and IE leads to CE enhancing the sustainable development (Figure 1). EIPs are based upon IE principles which suggest that industrial systems can operate like natural ecological systems (Jung et al., 2013: 50). EIP is based on the idea of the industrial symbiosis which aims to engage separated industries in a collective approach so that their economic performance is improved whereas their environmental footprints are reduced (Chertow, 2000; Fang et al., 2007; Oh et al., 2005: 271; Tibbs, 1992; Yu et al., 2014). EIPs enable engagement of separated industries through "significant, systematic industrial change" including physical exchange of materials and by-products, shared management of common utilities and infrastructures (Chertow, 2000; Fang et al., 2007; Tibbs, 1992; van Berkel, 2009; Yu et al., 2014). EIPs connect different waste-producing processes, plants, and consumers (Fang, 2003; Fang et al., 2007: 319). Panyathanakun et al. (2013: 71) emphasized that the ElPs enable not only tangible exchanges [i.e. the physical exchange of materials, energy, water, and by-product (Chertow, 2007)] but also intangible exchanges of knowledge and human or technical resources (Mirata and Emtairah, 2005). The exchanges of resources and collaboration among collaborative companies in the production process lead the emergence of synergy (Cote and Cohen-Rosenthal, 1998; Lowe, 1997; Panyathanakun et al., 2013: 71; Romerao and Ruiz, 2014: 394). "The collaborative community of companies in EIPs establish the 'industrial ecosystem'. (Lowe et al., 1996; Lowe, 2001; Veiga and Magrini, 2009: 653)” (Oh et al., 2005: 271)

EIPs can be established for new developments as well as for redevelopments of existing or obsolete industrial sites (Pellenbarg, 2002). Majority of the EIPs have been developed as a result of transformation of existing industrial parks (Mathews and Tan, 2011; Yu et al., 2014). As the enterprises in traditional industrial parks aimed at high economic output without considering the 'costs' of environmental degradation, 


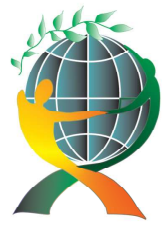

\author{
(online) $=$ ISSN $2285-3642$ \\ ISSN-L = $2285-3642$ \\ Journal of Economic Development, Environment and People \\ Volume 5, Issue 1, 2016 \\ URL: $\underline{\text { http://jedep.spiruharet.ro }}$ \\ e-mail: office jedep@spiruharet.ro
}

transformation of existing industrial parks into EIPs is expected to contribute to the solution of the environmental pollution problems and to the sustainable development path (Bai et al., 2014: 5). For this reason, EIPs are perceived as a new industrial model to address the three dimensions of sustainability, namely: social, economic and environmental (Veiga and Magrini, 2009: 653). EIPs have been established throughout the world [i.e. Europe (Baas and Boons, 2004; Tudor et al., 2007), China (Fang et al., 2007; Zhang et al., 2010), India (Singhal and Kapur, 2002), the Americas (Gibbs and Deutz, 2005, 2007), Australia (Roberts, 2004), and Japan (Berkel et al., 2009)] (Jung et al., 2013: 50).

CE, IE and EID support the sustainable society which relies on sustainable consumption, as well as on sustainable production (Lorek and Spangenberg, 2014). For this reason, change agents are needed to foster the EID. According to Wangel (2011: 873), the term 'agency' refers to 'the social' part of the socio-technical society, which consists of formal institutions (i.e. policies, taxes, and organisations), and informal institutions (i.e. norms, values, and social practices). Individuals and organisations having the capacity to act can act as agents (Wangel, 2011: 873). Sustainability leaders are the change agents who play the key role for the successful transformation towards sustainability, as well as for regional EID.

Changing unsustainable production has been identified as one of the objectives of sustainable development in the 2002 World Summit on Sustainable Development (UN, 2002; Barber, 2007: 499). There is need to foster EID as a tool to reduce environmental footprint of the production processes so that sustainable development can be achieved. For this reason, based on an in-depth literature review, this paper aims to analyze how EID can be supported so that environmental footprint of the production processes can be reduced contributing to sustainable development. With this aim, the objectives include: analysis of the need for the EID; need for the sustainable development enhanced by sustainable production and sustainable products; key success factors for, barriers against and drivers for the EID.

\title{
2. Sustainable Production and Companies as Change Agents for Sustainability
}

Companies acting as change agents for sustainability need to be active in the sustainable production so that they can support EID. Companies can be major contributors to sustainable development as they are perceived as major contributors to ecological problems (Clifton and Amran, 2011; Roy and Goll, 2014: 851852). Stakeholders' and consumers' growing pressures encourage companies in engaging in sustainability and in sustainable development, as well as in aligning the corporate values with those of the society (Matos and Silvestre, 2013; Musson, 2012; Seuring and Müller, 2008; Steurer, Langer, Konrad, and Martinuzzi, 2005). Corporate leaders and employees are increasingly recognising their role in contributing to sustainability (Lozano, 2012: 14). Companies in the supply chain, as consumers of resources throughout the production process play vital role as change agents for sustainable development. Their role can be supported by the EIPs which enable emergence of synergy especially with respect to tangible and intangible resources exchanges. As companies need to achieve economic success and their survival while enabling ecological protection (Clifton and Amran, 2011; Stead and Stead, 2000), they can be supported by the synergy of the EIPs.

Eco-labelling: Eco-labels support the EIPs aims as they encourage sustainable production which can be enhanced by increased synergy among the companies in the EIPs so that they can reduce their environmental footprints. Eco-labels provide the consumers information about the environmental impacts 


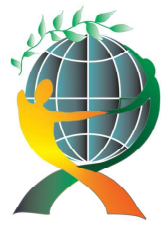

\author{
(online) $=$ ISSN $2285-3642$ \\ ISSN-L = 2285 - 3642 \\ Journal of Economic Development, Environment and People \\ Volume 5, Issue 1, 2016 \\ URL: http://jedep.spiruharet.ro \\ e-mail: office jedep@spiruharet.ro
}

of products (Reczkova et al., 2013: 498). For this reason, they have the potential for influencing consumers' purchasing decision towards environmentally friendly products (Reczkova et al., 2013: 498). They influence the individual consumers' demand for the end product, as well as the demand of the companies in the supply chain for sustainable/environmental friendly input materials or byproducts. Eco-labelling can act as a marketing tool. Advantages of certification and eco-labelling include (Chkanikova and Lehner, 2014):

- influencing consumers' demand for environmentally friendly and ethical products (Rex and Baumann, 2007; Elham and Nabsiah, 2011; Larceneux, Benoit-Moreau et al., 2011);

- encouraging sustainability improvements and their implementations 'upstream' in the supply chain (Burch and Lawrence, 2005; Deaton, 2004; Hatanaka, Bain et al., 2005; Henson and Humphrey, 2010; Seuring, 2011; Wu et al., 2010);

- allowing companies in the supply chain (e.g. retailers) to establish collaborative relationships with suppliers to improve product sustainability performance (Wu et al., 2010; Kogg and Mont, 2012);

- enabling the reduction of the transaction costs in appointing/assigning suppliers satisfying the sustainability criteria set for product's sustainability performance (Beckman et al., 2002; Vorley et al., 2002; Wathne and Heide, 2004);

- enabling the companies to purse differentiation strategy and to generate higher profit margins lowering production costs (European Commission, 2011a,b,c; Jung and Sung, 2008; Kotler, 2002; Orsato, 2009);

- encouraging the market for sustainable products (Chkanikova and Lehner, 2014);

- encouraging the companies to proactively address sustainability issues both upstream and downstream in the supply chain (Chkanikova and Lehner, 2014).

Policies and Government: Leadership is crucially important for the establishment and implementation of the effective policies needed for the EID. Governments are increasingly being held responsible for their sustainability performance (Roy and Goll, 2014: 849). Local governments should invest in a sustainable development policy to satisfy citizens and benefit companies and act with companies as partners to increase resilience and sustainability (Musson, 2012: 75). Policies play the key role in improving local and global sustainability (Editorial Journal of Cleaner Production, 2005: 967-969), as well as EID and EIPs. The recently carried out international meetings and programs (i.e. Rio+20, the Resource Efficiency and Cleaner Production Program, the Ten Year Framework of Programs on Sustainable Consumption and Production, the UN Resource Panel, and the Green Economy Initiative programs) emphasize the need for sustainability and sustainable production. Policymakers play key role in sustainable development as they can influence the sustainability transition. The policymakers need to act as sustainability leaders and avoid taking populist decisions which might harm the sustainability (Church and Lorek, 2007; Fuchs 2005; Lorek and Spangenberg, 2014: 40-41; Maniates, 2010a, b). The politicians need to enhance the citizens' interest in protecting the environment. As quoted from Jain et al. 2013: 20, there is need for '... 'rational-citizens' so that 'sensible' future for the upcoming generations can be achieved (Ravio, 2011; UNESCO, 1978)". Policymakers should encourage individuals to engage in a wide range of pro-environmental practices (Barr et al., 2011: 1224) as human capital accumulation magnifies the positive growth effects of policies that lower the rate of resource destruction, preserving the welfare of newborn agents (Valente, 2011: 995).

Policies can support establishment of EIPs and transformation of the existing industrial parks into EIPs (Boons et al., 2011; Lehtoranta et al., 2011; Mathews and Tan, 2011) especially through laws and 


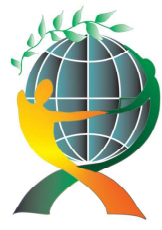

\author{
(online) $=$ ISSN $2285-3642$ \\ ISSN-L = $2285-3642$ \\ Journal of Economic Development, Environment and People \\ Volume 5, Issue 1, 2016 \\ URL: $\underline{\text { http://jedep.spiruharet.ro }}$ \\ e-mail: office jedep@spiruharet.ro
}

regulations (Yu et al., 2014: 466). Hard policies (i.e. regulatory and economic instruments) can influence consumption patterns (Rehfeld et al., 2007; ASCEE team 2008; Lorek et al., 2008). Policies and guidance can create synergy encouraging infrastructure sharing and company interaction (Gibbs et al., 2002; Mirata, 2004; Yu et al., 2014: 466).

Policies can support innovation which enhances sustainability performance of the production process, as well as of the product as "...technological improvements... must be combined with and integrated into structural change and sufficiency policy initiatives..." (Lorek and Spangenberg, 2014: 36).

Policies encouraging or requiring environmental friendly production and products can act as facilitators for consumers (companies in the supply chain) to prefer to work in the EIPs. Policies can encourage the consumers' (both individual consumers of the end product, as well as the companies in the supply chain) demand for products and production process having high sustainability performance. For example, the approaches which can support the sustainable consumption include (Akenji, 2014: 19-21): "taking out the unsustainable options from the market or making them less desirable (Maniates et al., 2010); integrating measures of well-being in the accounting for development (Harrison et al., 2005; Hobson, 2006); encouraging grassroots innovation and building communities; as well as defining limits of resource extraction and pollution".

\title{
Drivers for companies to act as change agents for EID
}

Drivers for companies to act as change agents for EID include: improvement of the sustainability performance; economic advantages and competitive advantage; regional development and future employability; policies and regulations.

Improvement of the sustainability performance: The requirements for improvement in the sustainability performance of the production process and of the products encourage the companies to work in the EIPs. Adverse effects of economic and environmental crisis encourage the politics to support CE, EID and transformation of industrial areas towards greater sustainability (Romero and Ruiz, 2014: 394). Sustainability and effective environmental protection have become a vital issue for the long-term development of industries, especially due to the limits of the availability in non-renewable resources, as well as due to limits of the biosphere's ability to absorb wastes (Cao et al., 2009: 2868-2876). EID can lead to the dematerialization of the production process; reduction in the environmental footprints of the production; as well as support of the regeneration of the world slowing down the deterioration rate through reduced resource consumptions and reduced environmental footprints of the production. EID can support the sustainability performance of the companies acting as consumers in the production process throughout the supply chain especially in the way they cope with barriers which can be encountered while adapting the sustainability principles. For example, the barriers faced by the precast concrete industry in enhancing the sustainability of their production process include (Holton et al., 2010: 154): difficulties encountered in the recruitment and retention of skilled staff; problems faced in the supply chain due to poor payment practices and increased transport costs. These barriers can be overcome with the help of the synergies which can be created by EIPs as they enable exchange of tangible and intangible assets among the companies in the EIPs. For this reason, the advantages and driving factors for enhancing companies' 


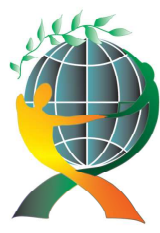

\author{
(online) $=$ ISSN $2285-3642$ \\ ISSN-L = $2285-3642$ \\ Journal of Economic Development, Environment and People \\ Volume 5, Issue 1, 2016 \\ URL: http://jedep.spiruharet.ro \\ e-mail: office jedep@spiruharet.ro
}

sustainability performance [e.g. need for recycling and reusing the waste due to increased costs of and restrictions on waste disposal (Holton et al., 2010: 154)] can also become possible drivers for companies (consumers in the supply chain) to act as change agent for EID.

EIPs can support lean, resilient and sustainable supply chain management practices of the companies. These practices can affect the sustainability of the supply chain especially through "waste elimination", "supply chain risk management" and "cleaner production" (Govindan et al., 2014). As the companies having lean, resilient and sustainable supply chain management can reduce all kinds of wastes and increase efficiency, they can be motivated to work in the EIPs so that they can exchange tangible and intangible resources.

EIPs can support innovation of sustainable products and sustainable production processes as they enable exchange of tangible and intangible assets among the companies in the EIPs. Technological innovation is important in achieving sustainability (Lorek and Spangenberg, 2014: 36). Radical innovations are needed to prevent nature from breaking down under the combined pressure of human population growth and the growth in the wealth per capita (Tukker and Butter, 2007: 102). Advancement in technology leads to the new substitution possibilities, as well as to the enhanced and improved technology for extraction, use and recycling (Barnett and Morse, 1973: 11). Furthermore, "what is sustainable today may not be so ten years from now." (Parzen et al., 1996: 27). Valente (2011: 996) emphasized the importance of innovation for sustainability stating that sustainability conditions are intimately linked to the development of innovations and that non declining consumption requires resource-augmenting technical progress. Advantages of innovation include:

- adaptation of eco-innovative approaches to companies' operations (Bocken et al., 2014: 43);

- production of new environmental friendly outputs (Bocken et al., 2014: 43) (i.e. regenerative materials/constructions);

- production based on "doing more with less" idea (Nakicenovic, 1996: 1);

- "... technical change for reduction in greenhouse gases and adaptation to climate change..." (Ausubel, 1995: 411);

- enabling decarbonization (Ausubel, 1995: 411) and dematerialization both of the product, as well as of the production process enabling increase in the energy efficiency, decrease in waste generation (Herman et al., 1990: 345), as well as decrease in raw material usage (Tchobanoglous et al., 1977).

As EID enhances sustainability performance of the production process, they can support future generations' interests.

Regional development and future employability: CE can provide economic and business opportunities (the Economic and business rationale for an accelerated transition report, 2012), as well as support future jobs and competitiveness (the European Commission 2012's Manifesto for a Resource Efficient Europe). EIDs can support improvement of the regional environmental performance and economic growth (Fang et al., 2007).

Economic advantages and competitive advantage: EIPs can enhance the competitiveness of the companies in the EIPs as they enable exchange of tangible and intangible resources, collaboration and learning among the companies in the EIP. EIPs can support the companies with respect to the synergy 


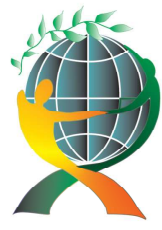

\author{
(online) $=$ ISSN $2285-3642$ \\ ISSN-L = 2285 - 3642 \\ Journal of Economic Development, Environment and People \\ Volume 5, Issue 1, 2016 \\ URL: http://jedep.spiruharet.ro \\ e-mail: office jedep@spiruharet.ro
}

created among the companies in EIPs through exchanging tangible and intangible resources; increased competitiveness of the companies in the EIPs mainly through reduced costs (i.e. usage of the resources efficiently) and increased profitability, as well as enhanced company image due to fulfilment of corporate social responsibility role with the help of environment friendly production process. EIPs can enable the companies in the EIPs to gain social, economic and ecological benefits especially through exchanges of tangible and intangible assets (Fang et al., 2007). Companies in the EIPs are motivated to collaborate due to potential economic benefits (Pakarinen et al., 2010: 1393). Collaboration among the companies can enhance their competitiveness as "...the only productive way forward is through collaboration and learning, rather than competition between different" (Tukker, 2013: 278) which can be enabled in the EIPs. EIPs can enhance the competitiveness of the companies as they support their lean and green supply chain management practices and innovation. The advantages and driving factors for enhancing companies' competitiveness [i.e. economic advantages (Vallaster and Lindgreen, 2013; Goger, 2013: 80); enhanced company image (Goger, 2013); internal branding and better communicated values in the workplace (Vallaster and Lindgreen, 2013: 298- 299); committed employees (Vallaster and Lindgreen, 2013: 298- 299); leading to long-term performance (Musson, 2012: 75); enhanced competitive advantage by i.e. lowering production costs through waste reduction and prolonged life or reuse of assets (Fiksel et al. 2004 as quoted from Hoejmose et al., 2012); upgraded value chain (Goger, 2013: 75); need for energy efficiency due to increased energy costs; need for reducing resource consumption (Holton et al., 2010: 154); enhanced organisational performance, reduced cost, and increased productivity (Aras et al., 2010; De Oliveira et al., 2010; Iraldo et al., 2009; Maletic et al. 2014; Michelon et al., 2012); differentiation for improving companies' future performance (Bose and Luo, 2011; Gupta and Kumar, 2013: 312)] can also become possible drivers for companies (consumers in the supply chain) to act as change agent for EID.

Policies and regulations: Policies and regulations can act as facilitators and as driving factors for EID in case they support EID and enhanced sustainability performance. Furthermore, governments can support the EIPs to catch the sustainability targets set in international protocols.

Barriers against EID include: unawareness of the consumers, and company specific characteristics.

Unawareness of the consumers: Individual consumers demand for sustainable products can encourage the companies to enhance their products and their production processes' sustainability qualifications whereas the individual consumers' demand not in favour of sustainable products can demotivate the companies to engage in GSCM practices (Porter and Kramer, 2006). For this reason, individual consumers of the end product need to "...recognise the roles, responsibilities and actions businesses have towards the health of the ecological environment in which businesses interact and operate (Rondinelli and Berry, 2000)" (Gupta and Kumar, 2013: 312). Companies need to persuade their customers about the initiatives they take for the welfare of society through brand communications as sustainability-based brand knowledge drives customers favourably towards the brand (Bridges and Wilhelm, 2008; Rust et al., 2004; Gupta and Kumar, 2013: 312).

Company specific characteristics: EID can encounter barriers emerged due to regulations and distrust among actors (Gibbs and Deutz, 2007; Heeres et al., 2004; Yu et al. 2014: 464); internal factors of the companies including internal politics and norms (Carter and Rogers, 2008; Govindan et al., 2014). EIPs' 


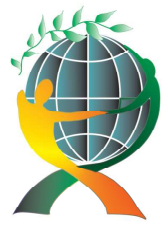

\author{
(online) $=$ ISSN $2285-3642$ \\ ISSN-L = 2285 - 3642 \\ Journal of Economic Development, Environment and People \\ Volume 5, Issue 1, 2016 \\ URL: $\underline{\text { http://jedep.spiruharet.ro }}$ \\ e-mail: office jedep@spiruharet.ro
}

success depends on (Sakr et al., 2011: 1163): symbiotic business relationships; economic value added; awareness and information sharing; policy and regulatory frameworks; organizational and institutional setups, and technical factors.

\title{
3. Key Success Factors for EID
}

EID in Europe, America, North Africa and Asia Pacific regions have been analyzed to investigate the key success factors for EID and EIPs. EIDs in different countries have been presented in the following paragraphs from the EIPs developments point of views.

EIPs in Europe: There are EIPs in Europe which are in different development phases, namely in operational, pre-operational, planned, or attempted phases (Sakr et al., 2011). The EU legislation also supports the CE and EID. For example, the EU legislation's lead to the reverse logistic enterprises for remanufacturing and recycling (Fang et al., 2007: 324). This legislation can also encourage the companies to work in the EIPs. Furthermore, flexibility of regulatory requirements on performance standards (Ehrenfeld and Gertler, 1997 and Desrochers, 2001), as well as regular monitoring and evaluation of EIPs (Geng et al., 2009a), as observed in the EU, support the EID. Similarly, sustainable development in the UK is encouraged by government through the use of sectoral strategies and government policies (i.e. the National Industrial Symbiosis Program in the UK supports the EIP development in the UK) (Glass and Pocklington, 2002: 1457; Yu et al., 2014: 464). The industries in the EU, such as cement and concrete sector, tend to actively enhance their sustainability performance via the environmental management systems (i.e. ISO 14000) and integration of the sustainability related targets into the company and sectoral sustainability strategies (Glass and Pocklington, 2002: 1457). One of the well-known EIPs in the EU is the industrial symbiosis network in Kalundborg, in Denmark (Cao et al., 2009). The Kalundborg EIP provided evidence of feasibility of embedding sustainability into production process and of enhancing environmental performance of the production process. Due to water scarcity, six major companies in Kalundborg spontaneously formed a symbiotic network (Chertow, 2000; Desrochers, 2001b; Jacobsen, 2006; Pakarinen et al. 2010: 1394; Yu et al., 2014: 464). Companies in Kalundborg EIP reuse each other's waste as by-products.

EIPs in America: There are more than 60 eco-industrial networking projects in Canada and the United States, however, approximately 17 out of them are operational with completed projects (Peck, 2002; Sakr et al. 2011: 1160). Most of the EIPs in the US have been developed to foster applications of IE to industrial parks through the President's Council on Sustainable Development and US Environmental Protection Agency (Sakr et al., 2011: 1160). ElPs in Brazil are at an early stage of development (Veiga and Magrini, 2009: 660). EIPs are perceived in Brazil as a potential environmental planning strategy to foster sustainable development and to improve the degraded urban and environmental condition (Veiga and Magrini, 2009: 660). EIP development in Brazil highlighted the need for (Veiga and Magrini, 2009: 660): enhancing collaboration among governments, private institutions and industries, communities and academia; overcoming the reluctance of the state government in supporting the EIPs due to changes in political administrations and public agency leadership; and enlarging the scope of EIP idea to cover the environmental planning strategy for sustainable development.

EIPs in North Africa: As the industrial sector in Egypt is considered as vital for economic and social development of Egypt, there are approximately 80 industrial cities and zones in Egypt (IDA, 2010 as quoted 


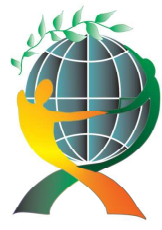

\author{
(online) $=$ ISSN $2285-3642$ \\ ISSN-L = 2285 - 3642 \\ Journal of Economic Development, Environment and People \\ Volume 5, Issue 1, 2016 \\ URL: http://jedep.spiruharet.ro \\ e-mail: office jedep@spiruharet.ro
}

by Sakr et al., 2011: 1159). There are, however, no ElPs in Egypt (Sakr et al., 2011: 1159-1160). The two pioneer programmes, namely the Environmentally Friendly New Industrial Cities Program (supported by the Ministry of State for Environmental Affairs) and the Integrated Industrial Solid Waste Management in Egypt project (supported by the EU LIFE Third Countries in cooperation with the Egyptian Environmental Affairs Agency) by which were targeted the improvement of environmental performance on the scale of an industrial estate, failed to meet their targets (Sakr et al., 2011: 1161-1162).

EIPs in the Asia Pacific region: During 1970s, China has transformed her planned economy to market based economy. After such transformation, foreign trade and investment has enhanced economic development (Cao et al., 2009: 2868-2876). Due to this rapid economic development, China has established EIPs in order to provide sustainable economic development (Zhu and Cote, 2004: 1025). That's why China launched EIP project in 1999, through this project industrial wastes are reduced and recycled. "The recycled materials are also used as inputs by enterprises within the park (Fang et al., 2007; Yuan et al., 2006; Zhang et al., 2010a)." (Zhang, et al., 2014: 1). After a decade in the year 2002 China's central government formally adopted the CE concept. "By 2013, 20 national eco-industrial demonstration parks had been approved, and 56 additional parks had been approved for construction (MEP, 2013)." (Zhang, et al., 2014: 1). The industrial parks that were first to adopt ecological evolution activities generally focused on sector-specific parks (e.g. sugar, electrolytic aluminium, salt-to-chemicals industry) whereas gradually, ecological evolution activities were extended to multi-sector parks (Bai et al., 2014: 5). China's government promotes EID through demonstration sites for EIPs, demonstration city and province for CE, as well as through policies, incentives, research and education (Fang et al., 2007: 327). In China, there are EIPs managed by (Fang et al., 2007: 317): enterprise groups (i.e. Guigang, Baotou, Lubei, and Fushun); the Management Commission of the Development Zone (i.e. Nanhai, Huangxing, Dalian Economic Development Zone, Tianjin Economic Development Zone); and local government (i.e. The Guiyang city and Liaoning province demonstration sites for CE). Some of the leading EIPs in China include: Guigang eco-industrial cluster (Fang et al., 2007: 318); the Guitang Group (Zhu and Cote, 2004: 1025); the Nanhai site (Fang et al., 2007: 318); the Shenyang Tiexi New District (Fang et al., 2007: 318); the Dalian economic and technology development zone (Fang et al., 2007: 318 and Bai et al., 2014: 5).

South Korea's EIP development strategy is based on the transformation of the industrial complexes into EIPs. EIP initiatives have been launched in 2005 (Jung et al., 2013: 50) and embarked by the Ministry of Knowledge Economy. Daedok Technovalley Development Project was the Korea's first attempt to design EIP by restructuring a conventional industrial estate development plan (Oh et al., 2005: 269). The South Korean EIP development plan consists of three phases as (Jung et al., 2013: 50-59):

- The first phase (2005-2009) covered pilot projects for transforming industrial complexes into EIPs. Furthermore, environmental education and awareness campaigns were conducted (Park et al., 2008).

- The second phase (2010-2014) aimed to widespread the dissemination of the EIP concept to industrial parks and to increase the quantities of EIPs.

- The third phase (2015-2019) is planned to analyse the lessons learnt from the previous two phases and would be fed back into the system/plan. 


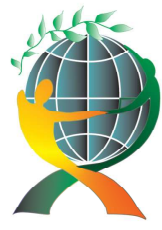

\author{
(online) $=$ ISSN $2285-3642$ \\ ISSN-L = $2285-3642$ \\ Journal of Economic Development, Environment and People \\ Volume 5, Issue 1, 2016
}

URL: http://jedep.spiruharet.ro

e-mail: office jedep@spiruharet.ro

EIPs developments in Europe, America, North Africa and Asia Pacific revealed the importance of the following key factors for EID:

- laws and legislation supporting reverse logistics, sustainable development (Fang et al., 2007);

- flexibility of regulatory requirements on performance standards (Ehrenfeld and Gertler, 1997 and Desrochers, 2001), as well as;

- regular monitoring and evaluation of EIPs (Geng et al., 2009a);

- governments' supports;

- sectoral strategies and government policies (i.e. the National Industrial Symbiosis Program in the UK supports the EIP development in the UK) (Glass and Pocklington, 2002: 1457; Yu et al., 2014: 464);

- enhancing collaboration among governments, private institutions and industries, communities and academia; overcoming the reluctance of the state government in supporting the EIPs due to changes in political administrations and public agency leadership; and enlarging the scope of EIP idea to cover the environmental planning strategy for sustainable development (Veiga and Magrini, 2009: 660);

- launching pilot EIPs.

\title{
4. Discussion
}

Promoting sustainable production is among the objectives of sustainable development (UN, 2002; Barber, 2007: 499). CE, IE and EID play important role in the sustainable development as they support sustainable production (Lorek and Spangenberg, 2014) and as companies are perceived as major contributors to ecological problems (Clifton and Amran, 2011; Roy and Goll, 2014: 851-852). For this reason, EID needs to be fostered and the companies need to be encouraged to act as change agents for sustainability producing in the EIPs and supporting EID. In this way, environmental footprint of the production processes can be minimized and companies can get benefit from producing in the EIPs (e.g. improvement of the sustainability performance; economic advantages and competitive advantage). Furthermore, social benefits can be obtained (e.g. regional development and future employability) supporting sustainable development. Companies, however, can encounter barriers (e.g. unawareness of the consumers, and company specific characteristics). Consumers' awareness for sustainable products and importance for sustainable production processes can affect their demand for the products of the companies in the EIPs. For this reason, enhancing consumers' awareness through formal or informal education, and media plays important role in increasing their demand for sustainable products encouraging the companies to invest in sustainable production processes and in producing in the EIPs. Consumers' demand for sustainable products and companies' willingness to produce in the EIPs can be encouraged by relevant laws and regulations. Furthermore, countries' policies need to encourage EID benchmarking from past experiences of the countries where EID has been successfully achieved. Factors which need to be considered by the countries and their policymakers wishing to widespread the EID have been summarized in the Table 1.

Table 1: Factors for encouraging the EID and sustainable development

\begin{tabular}{|l|l|l|}
\hline Factors & References \\
\hline Countries need to establish laws and legislation supporting reverse logistics, & Fang et al. (2007) \\
\hline
\end{tabular}




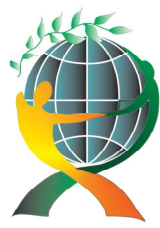

\author{
(online) $=$ ISSN $2285-3642$ \\ ISSN-L = $2285-3642$ \\ Journal of Economic Development, Environment and People \\ Volume 5, Issue 1, 2016
}

URL: http://jedep.spiruharet.ro

e-mail: office jedep@spiruharet.ro

\begin{tabular}{|c|c|}
\hline su & \\
\hline \multicolumn{2}{|l|}{$\begin{array}{l}\text { Laws and regulations need to encourage consumers' demand for sustainable products } \\
\text { and companies' willingness to produce in the EIPs. }\end{array}$} \\
\hline $\begin{array}{l}\text { Laws and regulations need to provide flexibility of regulatory requirements on } \\
\text { performance standards. }\end{array}$ & $\begin{array}{l}\text { Ehrenfeld and } \\
\text { Gertler (1997), } \\
\text { Desrochers (2001) }\end{array}$ \\
\hline Countries need to perform regular monitoring and evaluation of EIPs. & Geng et al. (2009a) \\
\hline $\begin{array}{l}\text { Countries need to encourage collaboration among governments, private institutions } \\
\text { and industries, communities and academia, as well as sectoral strategies and } \\
\text { government policies; and to provide steady political environment for development of } \\
\text { EIPs. }\end{array}$ & $\begin{array}{l}\text { Glass and } \\
\text { Pocklington (2002: } \\
\text { 1457), Veiga and } \\
\text { Magrini (2009: 660), } \\
\text { Yu et al. (2014: 464) }\end{array}$ \\
\hline \multicolumn{2}{|l|}{ Countries need to launch pilot EIPs. } \\
\hline \multicolumn{2}{|l|}{$\begin{array}{l}\text { Consumers' awareness for sustainable products and importance for sustainable } \\
\text { production processes need to be enhanced through formal or informal education, and } \\
\text { media plays important role in increasing their demand for sustainable products. }\end{array}$} \\
\hline $\begin{array}{l}\text { Eco-labelling need to be supported as they provide consumers information about the } \\
\text { environmental impacts of products. }\end{array}$ & $\begin{array}{l}\text { Reczkova et } \\
(2013: 498)\end{array}$ \\
\hline \multicolumn{2}{|l|}{$\begin{array}{l}\text { Countries' policies need to encourage EID benchmarking from past experiences of the } \\
\text { countries where EID has been successfully achieved. }\end{array}$} \\
\hline $\begin{array}{l}\text { International collaboration is needed to reduce environmental footprint of the } \\
\text { production processes and to enhance EID. }\end{array}$ & \\
\hline
\end{tabular}

\title{
5. Conclusions
}

This paper focuses upon the EID as a key for reducing environmental footprint of production. Based on an in-depth literature review, this paper analyses the need for the EID; sustainable development enhanced by sustainable production and sustainable products; as well as key success factors for, barriers against and drivers for the EID.

The world's habitat is being deteriorated especially due to the unsustainable production and consumption. There is an increase in the global consumption of natural resources (Rohn et al., 2014: 32). CE and IE enhanced by the EID need to be encouraged for reducing humanities' environmental footprint. CE, IE and EID can support sustainable society which relies on sustainable consumption, as well as on sustainable production (Lorek and Spangenberg, 2014). For this reason, companies acting as change agents are needed to foster the EID. Facilitators for transformation of companies into change agents for EID include: ecolabelling, policies and government.

- Eco-labelling: Eco-labelling influences the individual consumers' demand for the end product, as well as the demand of the companies in the supply chain for sustainable/environmental friendly input materials or by-products. Eco-labelling encourages sustainable production which can be enhanced by increased synergy among the companies in the EIPs so that they can reduce their environmental footprints.

- Policies and governments: Policies and governments can act as facilitators and as driving factors for EID. Policies should encourage the citizens' involvement to increase their effectiveness. 


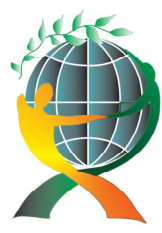

\author{
(online) $=$ ISSN $2285-3642$ \\ ISSN-L = $2285-3642$ \\ Journal of Economic Development, Environment and People \\ Volume 5, Issue 1, 2016 \\ URL: http://jedep.spiruharet.ro \\ e-mail: office jedep@spiruharet.ro
}

Drivers for companies to act as change agents for EID include: improvement of the sustainability performance; regional development and future employability; economic advantages and competitive advantage; policies and regulations.

- Improvement of the sustainability performance: The requirements for improvement in the sustainability performance of the production process and of the products encourage the companies to work in the EIPs. EIPs can support lean, resilient and green supply chain management practices of the companies, as well as innovation of sustainable products and sustainable production processes as they enable exchange of tangible and intangible assets among the companies in the EIPs.

- Regional development and future employability: EIDs can support improvement of the regional environmental performance and economic growth (Fang et al., 2007).

- Economic advantages and competitive advantage: EIPs can support the companies with respect to the synergy created among the companies in EIPs through exchanging tangible and intangible resources; increased competitiveness of the companies in the EIPs mainly through reduced costs (i.e. usage of the resources efficiently) and increased profitability, as well as enhanced company image due to fulfilment of corporate social responsibility role with the help of environment friendly production process. EIPs can enable the companies in the EIPs to gain social, economic and ecological benefits especially through exchanges of tangible and intangible assets (Fang et al., 2007).

- Policies and regulations: Requirements of the laws and regulations for environmental friendly production and products can act as facilitators and as driving factors for EID. International protocols and agreements on sustainability targets can enable the governments to encourage EID as well.

Barriers against EID include: consumers who do not demand for or who are not aware of the sustainable products or sustainable production process, and company specific obstacles (e.g. regulations; working culture; organizational structure).

The governments are recommended to consider the key success factors for the EID so that they can widespread EIPs. Based on analysis of the EIPs' developments in Europe, America, North Africa and Asia Pacific, the following key factors for EID have been revealed:

- Governments should be keen in supporting EID.

- Governments should prepare laws and legislations which support reverse logistics, sustainable development (Fang et al., 2007).

- Governments should provide flexibility in regulatory requirements with respect to the performance standards (Ehrenfeld and Gertler, 1997 and Desrochers, 2001).

- Governments should establish a system for regular monitoring and evaluation of EIPs (Geng et al., 2009a), as well as sectoral strategies and government policies (i.e. the National Industrial Symbiosis Program in the UK supports the EIP development in the UK) (Glass and Pocklington, 2002: 1457; Yu et al., 2014: 464).

- Governments should encourage collaboration among governments, private institutions, industries, communities and academia (Veiga and Magrini, 2009: 660).

- Governments can start the EID launching pilot EIPs. 


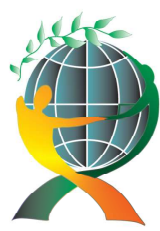

\author{
(online) $=$ ISSN $2285-3642$ \\ ISSN-L = $2285-3642$ \\ Journal of Economic Development, Environment and People \\ Volume 5, Issue 1, 2016 \\ URL: http://jedep.spiruharet.ro \\ e-mail: office jedep@spiruharet.ro
}

Furthermore, the governments are recommended to consider the facilitators for transforming the consumers into change agents for EID as their policies' effectiveness can be enhanced with the help of citizens' involvement in the process. The governments are also recommended to consider the driving factors for and barriers against the EID so that they can take necessary precautions on time. Widespreading EID throughout the world can support the sustainability performance of the production processes reducing environmental footprint of the humanity. For this reason, international collaboration on how to support and encourage establishment of EID needs to be fostered. Further researches are recommended to be carried out on political aspects of the EID at the international level focusing on how to motivate governments in establishing EIPs and the companies to operate in the EIPs, as well as on the international laws and trade regulations needed to drive establishment of the EIDs worldwide.

\title{
6. References
}

[1] Aarhus Convention Strategic Plan, (13 June 2008). Vision and Mission, third meeting of the parties to the Aarhus convention, Riga, Latvia.

[2] Agenda 21: Earth Summit - The United Nations Programme of Action from Rio 1992.

[3] Aras, G., Aybars, A., Kutlu, O. (2010). Managing corporate performance: investigating the relationship between corporate social responsibility and financial performance in emerging markets. Int. J. Prod. Perform. Manag. 59 (3), 229-254.

[4] Akenji, L. (2014). Consumer scapegoatism and limits to green consumerism, Journal of Cleaner Produc. 63, 13-23.

[5] Ausubel, J.H. (1995). Technical progress and climatic change, Energy Policy, 23(4/5), 411-416.

[6] Ayres RU, Ayres LU. (1996). Industrial ecology: towards closing the materials cycle. Cheltenham(UK): Edward Elgar, 278-80

[7] Baas, L.W., Boons, F.A. (2004). An industrial ecology project in practice: exploring the boundaries of decisionmaking levels in regional industrial systems. Journal of Cleaner Production 12 (8-10), 1073-1085.

[8] Bai, L., Qiao, Q., Yao, Y., Guo, J., and Xi, M. (2014). Insights on the development progress of National Demonstration eco-industrial parks in China. Journal of Cleaner Production 70 (2014) 4-14.

[9] Barber, J. (2007). Mapping the movement to achieve sustainable production and consumption in North America. Journal of Cleaner Production 15, 499-512.

[10] Barr, S., Gilg, A., Shaw, G. (2011). Citizens, consumers and sustainability: (Re)Framing environmental practice in an age of climate change. Global Environmental Change, 21, 1224-1233.

[11] Barnett, H.J., Morse, C. (1973). Scarcity and Growth: The Economics of Natural Resource Availability. John Hopkins University Press, Baltimore.

[12] United Nations (2002). Plan of implementation of the world summit on sustainable development. New York: United Nations [x2].

[13] Berkel, R.V., Fujita, T., et al. (2009). Industrial and urban symbiosis in Japan: analysis of the Eco-Town program 1997-2006. Journal of Environmental Management 90 (3), 1544-1557.

[14] Bocken, N.M.P., Farracho, M., Bosworth, R., and Kemp, R. (2014). The front-end of eco-innovation for ecoinnovative small and medium sized companies. J. Eng. Technol. Manage. 31, 43-57. 


\author{
(online) $=$ ISSN $2285-3642$ \\ ISSN-L = 2285 - 3642 \\ Journal of Economic Development, Environment and People \\ Volume 5, Issue 1, 2016 \\ URL: http://jedep.spiruharet.ro \\ e-mail: office jedep@spiruharet.ro
}

[15] Boons, F., Spekkink, W., et al. (2011). The dynamics of industrial symbiosis: a proposal for a conceptual framework based upon a comprehensive literature review. Journal of Cleaner Production 19 (9-10), 905-911.

[16] Boons, F. (2008). Self-organization and sustainability: the emergence of a regional industrial ecology. Emergence: Complexity and Organization, 10.

[17] Bose, R., and Luo, X. (2011). Integrative framework for assessing firms' potential to undertake green IT initiatives via virtualization - a theoretical perspective. Journal of Strategic Information Systems, 20(1), 38-54.

[18] Bridges, C. M., and Wilhelm, W. B. (2008). Going beyond green: The 'why and how' of integrating sustainability

[19] Bruyn, S. (1998). Chapter 10 Dematerialisation and rematerialisation Two sides of the same coin, Springer, in Managing a Material World Environment \& Policy Volume 13, Springer, 147-164.

[20] Burch, D., and Lawrence, G. (2005). Supermarket own brands, supply chains and the transformation of the agrifood system. Int. J. Sociol. Agric. Food 13 (1), 1-18.

[21] Burstro M. F., and Korhonen, J. (2001). Municipalities and industrial ecology: reconsidering municipal environmental management. Sustainable Development 9, 36-46.

[22] Cao, K., Feng, X., and Wan, H. (2009). Applying agent-based modelling to the evolution of ecoindustrial systems. Ecological Economics, 68, 2868-2876.

[23] Carter, C.R., and Rogers, D.S. (2008). A framework of sustainable supply chain management: moving toward new theory. International Journal of Physical Distribution and Logistics Management 38(5), 360-387.

[24] Carvalho, M., G., Bonifacio, M., and Dechamps, P. (2011). Building a low carbon society, Energy 36, $1842-1847$.

[25] Carvalho, H., Duarte, S., Cruz-Machado, V. (2011). Lean, agile, resilient and green: divergencies and synergies. Int. J. Lean Six Sigma 2 (2), 151-179.

[26] Chatterton, P., Goddard, J. (2000). The response of higher education institutions to regional needs. European Journal of Education 35 (4), 475-496.

[27] Chertow, M.R. (2007). Uncovering industrial symbiosis. Journal of Industrial Ecology 11 (1), 11-30.

[28] Chertow MR. (2000) Industrial symbiosis: literature and taxonomy. Annual Review of Energy and Environment. 25, 313-37.

[29] Chkanikova, O., and Lehner, M. (2014). Private eco-brands and green market development: towards new forms of sustainability governance in the food retailing, Journal of Cleaner Production (2014), http://dx.doi.org/10.1016/j.jclepro.2014.05.055

[30] Clarke, J., Newman, J., Smith, N., Vidler, E., Westmarland, L. (2007). Creating Citizen-Consumers: Changing Publics and Changing Public Services. Sage, London.

[31] Clifton, D., and Amran, A. (2011). The stakeholder approach: A sustainability perspective. Journal of Business Ethics, 98, 121-136.

[32] Clugson, R.M. (2004). Foreword. In: Corcoran, P.B., Wals, A.E.J. (Eds.), Higher Education and the Challenge of Sustainability: Problematics, Promise, and Practice. Kluwer Academic Publishers, Dordrecht, pp. ix-xi.

[33] Cogoy, M. (1999). The consumer as a social and environmental actor. Ecological Economics, 28, 385-398.

[34] Cohen-Rosenthal, E. (2003). What is eco-industrial development? Greenleaf publishing http://greenleafpublishing.com/content/pdfs/eich1.pdf 


\author{
(online) $=$ ISSN $2285-3642$ \\ ISSN-L = $2285-3642$ \\ Journal of Economic Development, Environment and People \\ Volume 5, Issue 1, 2016 \\ URL: http://jedep.spiruharet.ro \\ e-mail: office jedep@spiruharet.ro
}

[35] Cortese, A.D. The Critical Role of Higher Education in Creating a Sustainable Future, Planning for Higher Education, 15-22.

[36] Cortese, AD. (2008). Higher education's critical role in creating a healthy, just, and sustainable society. In: Simpson W, editor. The Green Campus: meeting the challenge of environmental sustainability. Alexandria, Virginia: APPA.

[37] Davis, S.A., Edmister, J.H., Sullivan, K., and West, C.K. (2003). Educating sustainable societies for the twenty-first century, International Journal of Sustainability in Higher Education, Vol. 4 No. 2, 169-179.

[38] Deaton, J. (2004). A theoretical frame for examining the role of third-party certifiers. Food Control 15, 615-619.

[39] De Oliveira, O.J., Serra, J.R., Salgado, M.H. (2010). Does ISO 14001 work in Brazil? J. Clean. Prod. 18, 1797-1806.

[40] Desrochers, P. (2001). Eco-industrial parks: the case for private planning. The Independent Review V (3), $345-371$.

[41] Desrochers, P. (2001b). Cities and industrial symbiosis: some historical perspectives and policy implications. J Ind Ecol. 5, 29-44.

[42] Editorial (2005). Management and policy for sustainable consumption and production. Journal of Cleaner Production 13, 967-969.

[43] Ehrenfeld, J., Gertler, N. (1997). Industrial ecology in practice: the evolution of interdependence at Kalundborg. J Ind Ecol. 1, 67-79.

[44] Elham, R., Nabsiah, A.W. (2011). Investigation of green marketing tools' effect on consumers' purchase behaviour. Bus. Strategy Ser. 12 (2), 73-83.

[45] Escrigas, C. (2012). Foreword: sustainability and knowledge in contemporary society. In: GUNi, G.U.N.f.I. (Ed.), Higher Education in the World 4: Higher Education's Commitment to Sustainability: from Understanding to Action. Palgrave Macmillan, Basingstoke, pp. xix-xxv.

[46] European Commission (2011a). The Impact of Private Labels on the Competitiveness of the European Food Supply Chain. Luxembourg European Union (2011) 201

[47] European Commission (2011b). A Renewed EU Strategy 2011-14 for Corporate Social Responsibility

[48] European Commission (2011c). Services on Monitoring Retailers' REAP Commitments Consortium ESWI, Munich (2011) 145.

[49] Fang, Y., Raymond, P., et al. (2007). Industrial sustainability in China: practice and prospects for eco-industrial development. Journal of Environmental Management 83 (3), 315-329.

[50] Fang, Y., Cote, R., Qin, R. (2007). Industrial sustainability in China: Practice and prospects for ecoindustrial development. Journal of Environmental Management, 83, 315-328.

[51] Ferrer-Balas, D., Lozano, R., Huisingh, D., Buckland, H., Ysern, P, and Zilahy, G. (2010). Going beyond the rhetoric: system-wide changes in universities for sustainable societies, Journal of Cleaner Production, 18, 607-610.

[52] Fiksel, J., Lambert, D.M., Artman, L.B., Harris, J.A., and Share, H.M. (2004). Environmental excellence: the new supply chain edge. Supply Chain Management Review 8 (5), 50-57.

[53] Fliedner, G. (2008). Sustainability: a new lean principle. In: Proceedings of the 39th Annual Meeting of the Decision Sciences Institute, Baltimore, Maryland, pp. 3321-3326. 


\author{
(online) $=$ ISSN $2285-3642$ \\ ISSN-L = 2285 - 3642 \\ Journal of Economic Development, Environment and People \\ Volume 5, Issue 1, 2016 \\ URL: http://jedep.spiruharet.ro \\ e-mail: office jedep@spiruharet.ro
}

[54] Gaziulusoy, A.I., Boyle, C., and McDowall, R. (2013). System innovation for sustainability: systemic double-flow scenario method for companies. Journal of Cleaner Production, 45, 104-116.

[55] Gibbs, D., Deutz, P., Procter, A. (2002). Sustainability and the Local Economy: the Role of Ecoindustrial Parks. Ecosites and Eco-Centres in Europe, Brussels, Belgium.

[56] Gibbs, D., Deutz, P. (2005). Implementing industrial ecology? Planning for ecoindustrial parks in the USA. Geoforum 36, 452-464.

[57] Giddens, A. (1991). Modernity and Self-Identity: self and identity in the late modern age. Stanford University Press, Stanford, California.

[58] Glass, J. and Pocklington, D.N. (2002). Delivering sustainability throughout the building process: a study of the UK cement and concrete sector. Advances in Building Technology, Volume 2, 1457-1467.

[59] Goddard, J. The engagement of higher educational institutions in regional development: an overview of the opportunities and challenges, Globally Competitive, Locally

[60] Goger, A. (2013). The making of a 'business case' for environmental upgrading: Sri Lanka's ecofactories. Geoforum, 47, 73-83.

[61] Govindan, K., Kaliyan, M., Kannan, D. and Haq, A.N. (2014). Barriers analysis for green supply chain management implementation in Indian industries using analytic hierarchy process. Int. J. ProductionEconomics, 147, 555-568.

[62] Graedel, T.E., Allenby, B.R. (2003). Industrial ecology. 2nd ed. New Jersey, USA: AT\&T Pearson Education, Inc.

[63] Gupta, S., and Kumar, V. (2013). Sustainability as corporate culture of a brand for superior performance. Journal of World Business, 48, 311-320.

[64] Hancock, L., and Nuttman, S. (2014). Engaging higher education institutions in the challenge of sustainability: sustainable transport as a catalyst for action. Journal of Cleaner Production, 62, 62-71.

[65] Harrison, R., Newholm, T., Shaw, D. (Eds.), (2005). The Ethical Consumer. Sage, London.

[66] Heeres, R.R., Vermeulen, W.J.V., de Walle, F.B. (2004). Eco-industrial park initiatives in the USA and the Netherlands: first lessons. J. Clean. Prod. 12, 985-995.

[67] Herman, R., Ardekani, S.A., and Ausubel, J.H. (1990). Dematerialization. Technological Forecasting and Social Change, 38, 333-347.

[68] Hesselbarth, C. and Schaltegger, S. (2014). Educating change agents for sustainability - learnings from the first sustainability management master of business administration, 62, 24-36.

[69] Henson, S., Humphrey, J. (2010). Understanding the complexities of private standards in global agri-food chains as they impact developing countries. J. Dev. Stud. 46 (9), 1628-1646.

[70] Hobson, K. (2006). Competing discourses of sustainable consumption: does the 'Rationalization of lifestyles' make sense? In: Jackson, T. (Ed.), The Earthscan Reader in Sustainable Consumption. Earthscan, London, pp. 305-327.

[71] Hoejmose, S.U., and Adrien-Kirby, A.J. (2012). Socially and environmentally responsible procurement: A literature review and future research agenda of a managerial issue in the $21^{\text {st }}$ century, Journal of Purchasing and Supply Management, 18, 232-242.

[72] Holton, I., Glass, J., and Price, A.D.F. (2010). Managing for sustainability: findings from four company case studies in the UK precast concrete industry. Journal of Cleaner Production 18, 152-160. 


\author{
(online) $=$ ISSN $2285-3642$ \\ ISSN-L = $2285-3642$ \\ Journal of Economic Development, Environment and People \\ Volume 5, Issue 1, 2016 \\ URL: http://jedep.spiruharet.ro \\ e-mail: office jedep@spiruharet.ro
}

[73] Hoover, E., and Harder, M.K. (2014). What lies beneath the surface? The hidden complexities of organizational change for sustainability in higher education. Journal of Cleaner Production, xxx, 1-14.

[74] IDA, (2010). The Official Website for the Egyptian Industrial Development Authority. http://www.ida.gov.eg (accessed 30.01.10).

[75] Iraldo, F., Testa, F., Frey, M. (2009). Is an environmental management system able to influence environmental and competitive performance? The case of the eco-management and audit scheme (EMAS) in the European Union. J. Clean. Prod. 17, 1444-1452.

[76] Jackson, T. (2009). Prosperity without Growth: Economics for a Finite Planet. Earthscan, London.

[77] Jacobsen, NB. (2006). Industrial symbiosis in Kalundborg, Denmark: a quantitative assessment of economic and environmental aspects. J Ind Ecol. 10, 239-55.

[78] Jain, S., Aggarwal, P., Sharma, N., and Sharma, P. (2013). Fostering sustainability through education, research and practice: a case study of TERI University, Journal of Cleaner Production 61, 20-24.

[79] Jung, S., Dodbiba, G., Chae, S.H., and Fujita, T. (2013). A novel approach for evaluating the performance of ecoindustrial park pilot projects. Journal of Cleaner Production, 39, 50-59.

[80] Jung, J., and Sung, E Y. (2008). Consumer-based brand equity; comparisons among Americans and South Koreans in the USA and South Koreans in Korea. Consumer-Based Brand Equity Comp. Among Am. South Koreans USA. South Koreans Korea, 12 (1), 24-35

[81] Karatzoglou, B. (2013). An in-depth literature review of the evolving roles and contributions of universities to Education for Sustainable Development. Journal of Cleaner Production 49, 44-53.

[82] Kogg, B., Mont, O. (2012). Environmental and social responsibility in supply chains: the practise of choice and inter-organisational management. Ecol. Econ. 83, 154-163.

[83] Korhonen, J. (2007). Industrial ecology in the strategic sustainable development model strategic applications of industrial ecology. J Clean Prod, 12, 809-23.

[84] Kottler, P. (2002). Marketing Management. Millennium Edition. Pearson Custom Publishing, Boston.

[85] Larceneux, F., Benoit-Moreau, F., et al. (2011). Why might organic labels fail to influence consumer choices? Marginal labelling and brand equity effects. J. Consum. Policy. http://dx.doi.org/10.1007/s10603-011-9186-1.

[86] Lehtoranta, S., Nissinen, A., Mattila, T., Melanen, M. (2011). Industrial symbiosis and the policy instruments of sustainable consumption and production. J. Clean. Prod. 19, 1865-1875.

[87] Linnenluecke, M.K. and Griffiths, A. (2013). Firms and sustainability: Mapping the intellectual origins and structure of the corporate sustainability field. Global Environmental Change, 23, 382-391.

[88] Lorek, S. and Spangenberg, J.H. (2014). Sustainable consumption within a sustainable economy - beyond green growth and green economies, Journal of Cleaner Production 63, 33-44.

[89] Lowe, E.A. (2001). Eco-industrial Park Handbook for Asian Developing Countries?? Based upon Eco-Industrial Parks, a Handbook for Local Development Teams (1995-98), Indigo Development Working Papers in Industrial Ecology (1997-2001), and Field Experience in the Philippines, Thailand, and China. Report to Asian Development Bank. Indigo Development.

[90] Lowe, E. (2001). Handbook for development of eco-industrial parks, Indigo development, USA. Available from: http://indigodev.com 


\author{
(online) $=$ ISSN $2285-3642$ \\ ISSN-L = $2285-3642$ \\ Journal of Economic Development, Environment and People \\ Volume 5, Issue 1, 2016 \\ URL: http://jedep.spiruharet.ro \\ e-mail: office jedep@spiruharet.ro
}

[91] Lowe, E., Moran, S., and Holmes, D. (1996). Fieldbook for the Development of Eco-Industrial Parks, Indigo Development.

[92] Lowe, E., Moran, S., and Holmes, D. (1996). Fieldbook for the development of eco-industrial parks. Washington (DC): Report prepared for the Office of Policy, Planning and Evaluation, United States Environmental Protection Agency [Prepared by Indigo Development, Oakland, CA].

[93] Lozano, R. (2006a). Incorporation and institutionalization of SD into universities: breaking through barriers to change. J. Clean. Prod. 14, 787-796.

[94] Lown, J.J. (2003) Eco-industrial development and the resource conservation and recovery act: examining the barrier presumption http://www.bc.edu/content/dam/files/schools/law/lawreviews/journals/bcealr /30_2/01_FMS.htm Boston College Environmental Affairs, 30(2), 275-314.

[95] Maletic, M., Maletic, D., Dahlgaard, J.J., Dahlgaard-Park, S.M., Gomiscek, B. (2014). Sustainability exploration and sustainability exploitation: from a literature review towards a conceptual framework. Journal of Cleaner Production xxx, 1-13.

[96] Maniates, M. (2010). Editing out unsustainable behaviour. In: Assadourian, Erik, et al. (Eds.), State of the World 2010: Transforming Cultures, From Consumerism to Sustainability. W.W. Norton and Company, New York.

[97] “Manifesto for a Resource Efficient Europe”. European Commission. Retrieved 21 January 2013.

[98] Mathews, J.A., Tan, H. (2011). Progress toward a circular economy in China: the drivers (and inhibitors) of eco-industrial initiative. J. Ind. Ecol. 15, 435-457.

[99] Matos, S., and Silvestre, B.S. (2013). Managing stakeholder relations when developing sustainable business models: the case of the Brazilian energy sector. Journal of Cleaner Production, 45, 61-73.

[100] Meadows, D.H., Meadows, D.L., Randers, J., Behrens III, W.W. (1972). The Limits to Growth. Universe Books, New York.

[101] Michelon, G., Boesso, G., and Kumar, K. (2012). Examining the link between strategic corporate social responsibility and company performance: an analysis of the best corporate citizens. Corp. Soc. Responsib. Environ. Manag. http://dx.doi.org/10.1002/csr.1278.

[102] Mirata, M., Emtairah, T. (2005). Industrial symbiosis networks and the contribution to environmental innovation: the case of the Landskrona industrial symbiosis programme. 13, 993-1002.

[103] Musson, A. (2012). The build-up of local sustainable development politics: A case study of company leaders in France, Ecological Economics, 82, 75-87.

[104] Nakicenovic, N. (1996). Decarbonization: Doing More with Less. North Holland. Technological Forecasting and Social Change 51, 1-17.

[105] Oh, D.S., Kim, K.B., and Jeong, S.Y. (2005). Eco-Industrial Park Design: a Daedeok Technovalley case study. Habitat International, 29, 269-284.

[106] Orsato, R. (2009). Sustainable Strategies: When Does It Pay To Be Green? Palgrave Macmillan, Basingstoke, Hampshire, UK.

[107] Orr, D. (1994). Earth in mind, on education, environment, and the human prospect. Washington DC: Island Press. 


\author{
(online) $=$ ISSN $2285-3642$ \\ ISSN-L = $2285-3642$ \\ Journal of Economic Development, Environment and People \\ Volume 5, Issue 1, 2016 \\ URL: http://jedep.spiruharet.ro \\ e-mail: office jedep@spiruharet.ro
}

[108] Orr, D.W. (1995). Educating for the environment: higher education's challenge of the next century. Change 27, 43-46.

[109] Pakarinen, S., Mattila, T., Melanen, M., Nissinen, A., and Sokka, L. (2010). Sustainability and industrial symbiosis - The evolution of a Finnish forest industry complex. Resources, Conservation and Recycling, 54, 1393-1404.

[110] Panyathanakun, V., Tantayanon, S., Tingsabhat, C., and Charmondusit, K. (2013). Development of eco-industrial estates in Thailand: initiatives in the northern region community-based eco-industrial estate. Journal of Cleaner Production 51, 71-79.

[111] Peck, S. (2002). Industrial Ecology in North America: when is an eco-industrial park not an ecoindustrial park? Journal of Industrial Ecology 5 (3).

[112] Peer, V., and Stoeglehner, G. (2013). Universities as change agents for sustainability - framing the role of knowledge transfer and generation in regional development processes. Journal of Cleaner Production, 44, 8595.

[113] Pellenbarg, P.H. (2002). Sustainable business sites in the Netherlands: a survey of policies and experiences. Journal of Environmental Planning and Management 45 (1), 59-84.

[114] Porter, M., Kramer, M. (2006). The link between competitive advantage and corporate social responsibility. Harvard Business Review 84 (12), 78-92.

[115] Posch, P. (1999). The Ecologisation of Schools and its implications for educational policy. Cambridge Journal of Education, 29(3), 341-348.

[116] Quist, J., Rammelt, C., Overschie, M., and Werk, G. (2006). Backcasting for sustainability in engineering education: the case of Delft University of Technology. Journal of Cleaner Production, 14, 868-876.

[117] Reczkova, L., Sulaiman, J., Bahari, Z. (2013). Some issues of consumer preferences for eco-labelled fish to promote sustainable marine capture fisheries in peninsular Malaysia. PSU-USM International Conference on Humanities and Social Sciences. Procedia - Social and Behavioural Sciences, 91, 497 - 504.

[118] Rex, E., Baumann, H. (2007). Beyond eco-labels: what green marketing can learn from conventional marketing. J. Clean. Prod. 15, 567-576

[119] Roberts, B.H. (2004). The application of industrial ecology principles and planning guidelines for the development of eco-industrial parks: an Australian case study. Journal of Cleaner Production 12, 997-1010.

[120] Romero, E., and Ruiz, M.C. (2014). Proposal of an agent-based analytical model to convert industrial areas in industrial eco-systems. Science of the Total Environment 468-469, 394-405.

[121] Rondinelli, D. A., and Berry, M. A. (2000). Environmental citizenship in multinational corporations: Social responsibility and sustainable development. European Management Journal, 18(1), 70-84.

[122] Rosenthal, EC, Cote, RP. (1998). Designing eco-industrial parks: a synthesis of some experiences. Journal of Cleaner Production, 6, 181-8.

[123] Roy, A., and Goll, I. (2014). Predictors of various facets of sustainability of nations: The role of cultural and economic factors. International Business Review, 23, 849-861.

[124] Rust, R. T., Ambler, T., Carpenter, G. S., Kumar, V., \& Srivastava, R. K. (2004). Measuring marketing productivity: Current knowledge and future directions. Journal of Marketing, 68(4), 76-89. 


\author{
(online) $=$ ISSN $2285-3642$ \\ ISSN-L = $2285-3642$ \\ Journal of Economic Development, Environment and People \\ Volume 5, Issue 1, 2016 \\ URL: http://jedep.spiruharet.ro \\ e-mail: office jedep@spiruharet.ro
}

[125] Sakr, D., Baas, L., El-Haggar, S., and Huisingh, D. (2011). Critical success and limiting factors for eco-industrial parks: global trends and Egyptian context. Journal of Cleaner Production, 191, 158-1169.

[126] Schmitt, K. (2011). Going Big with Big Matters. The Key Points Approach to Sustainable Consumption. GAIA 20/4: 232 -235. In: GAIA Ecological Perspectives for Science and Society 21 (2), 91-94.

[127] Seuring, S., and Müller, M. (2008). From a literature review to a conceptual framework for sustainable supply chain management. Journal of Cleaner Production 16 (15), 1699-1710.

[128] Seuring, S. (2011). Supply chain management for sustainable products - insights from research applying mixed methodologies. Bus. Strategy Environ. 20 (7), 471-484.

[129] Sharp, L. (2002). Green campuses: the road from little victories to systemic transformation. Int. J. Sustain. High. Educ. 3, 128-145.

[130] Singhal, S., Kapur, A. (2002). Industrial estate planning and management in India an integrated approach towards industrial ecology. Journal of Environmental Management 66 (1), 19-29.

[131] Spaargaren, G., Mol, A.P.J. (2008). Greening global consumption: redefining politics and authority. Global Environmental Change 18, 350-359.

[132] Stead, J. G., Stead, E. (2000). Eco-enterprise: Standing for sustainability. Journal of Business Ethics, 24(4), 313329.

[133] Stephens J.C., Hernandez, M.E., Roman, M., Graham, A.C., Scholz, R.W. (2008). Higher education as a change agent for sustainability in different cultures and contexts. International Journal of Sustainability in Higher Education; 9 (3), 317-38.

[134] Su, B., Heshmati, A., Geng, Y., and Yu, X. (2013). A review of the circular economy in China: moving from rhetoric to implementation. Journal of Cleaner Production, 42, 215-227.

[135] Syed, S. (2014). Media As a Change Agent, Mass Media[?, http://saeedasyed.blogspot.com.tr/p/massmedia.html [Accessed: 28.03.2014]

[136] Tchobanoglous, G., Theisen, G.H., and Eliassen, R.E. (1977). Solid wastes-engineering principles and management issues, McGraw Hill, New York.

[137] The Central Committee of China Zhi Gong Party, (2004). Implementation circular economy model, transformation industrial base of Brownfield. Chinese Development 1, 24-28.

[138] Tibbs, H.B.C. (1992). Industrial ecology: an environmental agenda for industry, Center of Excellence for Sustainable Development, US Department of Energy, from http://www.Sustainable.doe.gov/articles/ indecol.html.

[139] Townsend, J., and Barrett, J. (2013). Exploring the applications of carbon footprinting towards sustainability at a UK university: reporting and decision making. Journal of Cleaner Production, 1-13.

[140] Tudor, T., Adam, E. et al. (2007). Drivers and limitations for the successful development and functioning of EIPs (eco-industrial parks): a literature review. Journal of Ecological Economics 61, 199-207.

[141] Tukker, A., and Butter, M. (2007). Governance of sustainable transitions: about the 4(0) ways to change the world. Journal of Cleaner Production, 15, 94-103.

[142] Tukker, A. (2013). Knowledge collaboration and learning by aligning global sustainability programs: reflections in the context of Rio+20. Journal of Cleaner Production, 48, 272-279. 


\author{
(online) $=$ ISSN $2285-3642$ \\ ISSN-L = $2285-3642$ \\ Journal of Economic Development, Environment and People \\ Volume 5, Issue 1, 2016 \\ URL: http://jedep.spiruharet.ro \\ e-mail: office jedep@spiruharet.ro
}

[143] Vallaster, C., and Lindgreen, A. (2013). The role of social interactions in building internal corporate brands: Implications for sustainability. Journal of World Business, 48, 297-310.

[144] Valente, S. (2011). Intergenerational externalities, sustainability and welfare - The ambiguous effect of optimal policies on resource depletion. Resource and Energy Economics, 33, 995-1014.

[145] van Berkel, R. (2009). Comparability of industrial Symbioses. J. Ind. Ecol. 13, 483-486.

[146] Veiga, L.B., and Magrini, A. (2009). Eco-industrial park development in Rio de Janeiro, Brazil: a tool for sustainable development. Journal of Cleaner Production 17 (2009) 653-661.

[147] Vergragt, P., Akenji, L., and Dewick, P. (2014). Sustainable production, consumption, and livelihoods: global and regional research perspectives. Journal of Cleaner Production, 63, 1-12.

[148] Vinodh, S., Arvind, K.R., Somanaathan, M. (2011). Clean Techn. Environ. Policy 13 (3), 469-479.

[149] Vorley, TAJN. (2008). (Re)Conceptualising the academy: Institutional development of and beyond the Third Mission. Higher Education Management and Policy, 20 (3).

[150] Vringer, K., and Blok, K. (2000). Long-term trends in direct and indirect household energy intensities: a factor in dematerialisation? Energy Policy 28, 713-727.

[151] Wangel, J. (2011). Exploring social structures and agency in backcasting studies for sustainable development. Technological Forecasting and Social Change, 78, 872-882.

[152] Wathne, K.H., Heide, J.B. (2004). Relationship governance in a supply chain network. J. Mark. 68 (1), $73-89$.

[153] Weizsacker, E.U.v., Lovins, A.B., Lovins, L.H. (1997). Factor Four. Doubling Wealth*/Halving Resource Use. Earthscan, London.

[154] Wieringa, K., de Vries, H. J. M., and Hoogervorst, N. J. P. (1992). National Environmental Outlook 1990-2010, Samson H. D. Tjeenk Willink BV, Alphen aan den Rijn, The Netherlands, 55-65.

[155] WiseGEEK (Clear answers for common questions) (2014) What Is Green GDP? http://www.wisegeek.com/whatis-green-gdp.htm

[156] Yu, C., Jong, M., and Dijkema, G.P.J. (2014). Process analysis of eco-industrial park development - the case of Tianjin, China. Journal of Cleaner Production 64, 464-477.

[157] Yuan, Z.W., Bi, J., Moriguichi, Y. (2006). The circular economy: a new development strategy in China. J. Ind. Ecol. 10, 4-8.

[158] Zhang, L., Yuan, Z.W., Bi, J., Zhang, B., Liu, B.B. (2010a). Eco-industrial parks: national pilot practices in China. J. Clean. Prod. 18, 504-509.

[159] Zhu, Q.H., and Côté, R.P. (2004). Integrating green supply chain management into an embryonic eco-industrial development: a case study of the Guitang Group. J. Clean. Prod. 12, 1025-1035.

[160] Zilahy, G. and Huisingh, D. (2009). The roles of academia in Regional Sustainability Initiatives, Journal of Cleaner Production, 17, 1057-1066. 